\title{
Capital Market Transmission Channels and Real Sector Performance in Nigeria (1984-2016): Implications for Economic Growth
}

\author{
Ayodeji, Emmanuel A. ${ }^{1}$, PhD, Ajala, Rosemary Bukola ${ }^{2}$, Awoniyi, C. Laoye ${ }^{3}$ \\ ${ }^{1}$ Senior Lecturer, Department of Banking and Finance, AfeBabalola University, Ado-Ekiti, Ekiti State, Nigeria \\ ${ }^{2}$ Department of Banking and Finance, The Federal Polytechnic, Ado-Ekiti, Ekiti State, Nigeria \\ ${ }^{3}$ Department of Banking and Finance, PhD Student, AfeBabalola University, Ado-Ekiti, Ekiti State, Nigeria
}

Corresponding Author: Ayodeji, Emmanuel A.

Lecturer, Department of Banking and Finance, AfeBabalola University, Ado-Ekiti, Ekiti State, Nigeria Ph.+234 7035797660

\begin{abstract}
The study examined the channels through which capital market impulses are transmitted to the real sector of the economy in the achievement of economic growth in Nigeria within the time frame 1984-2016. On the theoretical basis of the endogenous growth model of the finance-growth theory, the study identified four capital market transmission channels, which are the efficiency channel, savings-investment channel, liquidity transformation channel, and wealth creation channel. The efficiency channel was proxied by all-share index; savings-investment channel was proxied by market capitalization and number of listed equities; liquidity transformation channel was proxied by number of deals and stock market turnover; and wealth creation channel was proxied by value of deals and value of transactions. The study sourced time-series data, in relation to these proxies, from the capital market bulletins of the Nigerian Securities and Exchange Commission, and the annual reports and accounts of the Nigerian Stock Exchange, and estimated them using vector auto regression approach. The study found that, capital market variables exerted heterogeneous effects on and transmitted heterogeneous impulses to the real sector of the Nigerian economy. Not only that, significant variations in gross domestic product were caused by the liquidity transformation channel and partially by the savingsinvestment channel. Transposing gross domestic product against each of the capital market variables, it was found that, gross domestic product exerted positive influences on only number of deals and stock market turnover, that is, liquidity transformation channel. However, it exerted negative influences on efficiency, savings-investment and wealth creation channels. It was also found that, a unidirectional causality exists between capital market transmission channels and economic growth in Nigeria, running from savings-investment channel to economic growth, and running from liquidity transformation channel to economic growth. It was, therefore recommended that, the Nigerian capital market should be sanitized by fishing out bad eggs from its leadership and operators, and by reinforcing the criminalization of insider abuses and market infractions with stricter acts of parliament, so that public confidence can be restored in the market. Second, more regulatory infrastructures should be developed for the operations of the Nigerian capital market as additions to the already existing technology-driven Broker Oversight and Supervision System (X-BOSS). The additional infrastructures should be able to reflect the activities of listed companies. Third, training and development programmes, which aim at re-orientating the leadership and staff of the Securities and Exchange Commission, towards effective policing of the market, should be embarked upon.
\end{abstract}

Keywords: Capital market, transmission channels, real sector, economic growth, capitalization

\section{Introduction}

Basically, an economy is divided into the public sector and the private sector; and it is classified into the real sector and the financial sector. Essentially, the real sector is the sector of the economy that is involved in the production of goods and services for the creation of utility (utility is the power of a commodity to satisfy human wants). On the other hand, the financial sector is the sector of the economy that is involved in rendering financial services to economic agents (i.e. individuals, firms and governments). Thus, the financial sector renders financial services to the real sector of the economy. The real sector is otherwise referred to as the goods market, and it is sub-classified into commerce, industry, mines and agriculture, while the financial sector is often regarded as the financial market, which is subclassified into the money market and the capital market.

The real sector is the engine of growth, as commercial activities, industrial activities, mining activities and agricultural activities are the major components of Gross Domestic Product (GDP for short), so that a sustained increase in GDP growth rate would be tantamount to economic growth. However, the financial sector is the hub of the economy, and it serves as the lubricant for the running of the engine of growth in the economy, that is, the real 
sector. This is based on the fact that, the financial sector provides the financial services required by the real sector within the context of financial intermediation. In practical terms, the short-term capital needs of the real sector are provided for by the money market, while its medium to long-term capital needs are supplied by the capital market. Since economic growth is a sustained increase in GDP growth rate, it is, of essence, medium to long-term in nature, so that, it is the capital market that provides the capital funds required for the medium to long-term investments that would translate to the needed economic growth. Thus, the interactions between the capital market and the real sector are expected to engender economic growth.

The theoretical basis for these interactions is the finance-growth theory, which emanated from the McKinnon-Shaw hypothesis, and was advanced by endogenous growth model. One major stipulations of this theory is that, the capital market is a vehicle for achieving long-run economic growth. In relation to this, Oke and Adeusi (2012) noted that, every nation views economic growth and development to be the focus of their government, and no nation wants to be behind in terms of development pace. This is why all policies, including fiscal and monetary, centre on resource allocation and/ or distribution aiming at improving the channelling process of gearing savings into investment. Conformably, as noted by Ewah, Essang and Bassey (2009), the main objective of establishing the Nigerian capital market is to mobilize savings from numerous economic units for economic growth and development, provide adequate liquidity to investors, broaden the ownership base of assets as well as the creation of a buoyant private sector, and provide alternative source of fund for government.

Thus, the theoretical link between capital market and economic growth is based on the threshold of financial intermediation role of the capital market. Accordingly, Akinbohungbe (1996) asserted that, the whole essence of capital market is in its financial intermediation capacity by which it mobilizes funds from the surplus sector of the economy for productive use of the deficit sector in order to attain socio-economic growth and development. Similarly, Oke and Adeusi (2012) stressed the long-term financial intermediation function of the capital market for the development of the major sub-sectors of the real sector, and as such, noted that, capital market is the engine of growth and development, as it impacts positively on the real sector areas of the economy by providing them with financial resources through its financial intermediation capacity for the financing of long-term projects that are capable of engendering sustainable growth.

To corroborate the finance-growth theory, Yadirichukwu and Chigbu (2014) stated that, the capital market is expected to contribute to economic growth through the transmission mechanisms of savings mobilization, creation of liquidity, risk diversification, improved dissemination and acquisition of information, and provision of long-term non-debt financial capital. This assertion, essentially established the mechanisms or, better still, channels through which capital market impulses are transmitted to the real sector of the economy with the aim of achieving economic growth. For the purpose of simplicity, we advanced four basic capital market transmission channels based on the efficiency with which a capital market performs its traditional functions of funds mobilization, liquidity-creation and wealth creation. Thus, capital market transmission channels are efficiency channel, savingsinvestment channel, liquidity transformation channel and wealth creation channel.

Effectively, the efficiency channel, that is, efficiency in the performance of capital market functions, is reflected in all-share index, which tracks the general market efficiency. Not only is that, savings-investment channel, for funds mobilization and allocation, is reflected in market capitalization (which measures the extent of available public capital mobilized) and number of listed securities. Also, the liquidity transformation channel is manifested through number of deals, volume of transactions and market turnover. Lastly, wealth creation channel is represented by value of deals, value of transactions and/ or market return.

In extant literature, emphasis is not laid on capital market transmission channels in relation to economic growth; rather, it is placed on capital market performance and/ or development. For, available works on the link between capital market and economic growth concentrated on the effects or contributions of capital/ stock market to economic growth using Ordinary Least Squares (OLS) method of analysis with or without co-integration and/ or causality tests. Though OLS is useful, unrestricted Vector Auto Regression (VAR) and restricted VAR (i.e. vector error correction model) are more useful, as they measure how capital market impulses are transmitted through its transmission channels to the real sector of the economy for the achievement of economic growth.

Few studies which employed VAR include those of Carporale, Howells and Soliman (2004) and Olweny and Kimani (2011) which adopted VAR; and Akinlo and Akinlo (2009) and Anigbogu and Nduka (2014) which used restricted VAR. It was against this background that this study was initiated to examine the channels through which capital market impulses are transmitted to the real sector of the economy in the achievement of economic growth in Nigeria within the time frame 1984-2016. Arising from this, two research hyp0otheses were tested in this study; these are: First, there is no significant relationship between capital market transmission channels and economic growth in Nigeria. Second, there is no direction of causal relationship between capital market transmission channels and economic growth in Nigeria. 


\section{Literature Review \\ Conceptual Clarification}

Capital market transmission channels are the various mechanisms through which financial intermediation impulses from the capital market are conveyed to the real sector of the economy, so that real sector activities are influenced with the aim of attaining economic growth and development. Such impulses are drives, which are capable of spurring or influencing the level of real activities towards making significant contributions to the nation's Gross Domestic Product (GDP). Theoretically, positive contributions are expected, so that GDP growth rate can be increased, leading to economic growth. These channels, essentially, are the different contexts by which the major financial intermediation functions of the capital market are performed.

Yadirichukwu and Chigbu (2014) identified five capital market transmission channels; obviously, these can be seen as four. They are savings mobilization, liquidity creation, risk diversification, efficiency (i.e. improved dissemination and acquisition of information) and debtequity mix mechanism. Effectively, the last point is part of the third; however, as previously stated, we advanced four capital market transmission channels on the threshold of the capital market economic significance theorem developed by Ayodeji and Ajala (2018). This is due to the fact that, boosting the level of economic activities towards achieving output growth requires the development of the capital market in its performance of long-term financial intermediation functions. These transmission channels are: efficiency channel, savings-investment channel, liquidity transformation channel, and wealth creation channel. These are capable of being quantitatively measured by their attributable capital market performance indicators or indices.

Capital market performance, however, is the expression of efficiency in the functioning capacity of a capital market in mobilizing medium to long-term funds from the surplus sector to the deficit sector of the economy for economic growth and development purposes (Ayodeji \& Ajala, 2018). The implication of this, is that, capital market performance is expected to translate to economic growth. This is due to the fact that, medium to long-term capital is mobilized from the capital market for productive investments and development purposes. Massive productive investments would definitely translate into increase in agricultural and industrial production, mining and commercial activities and, hence, increase in gross domestic product, which is the proxy for economic growth.

The savings-investment channel transmits the effects of capital funds mobilization and allocation to the real sector of the economy for the achievement of economic growth. Accordingly, Osaze (2000) stated that, the capital market is the driver of any economy to growth and development because it is essential for the long-term growth capital formation. It is crucial in the mobilization of savings, and channelling of such savings to profitable self-liquidating investments. Corroborating this statement, Ekundayo (2002) argued that, a nation requires a lot of local and foreign investments to attain sustainable economic growth and development. The capital market provides a means through which this is made possible. To buttress this further, Briggs (2015) noted that, the development of the financial sector also closely tracks economic transformation. A welldeveloped financial system mobilizes and pools savings, facilitates the exchange of goods and services, and allows the diversification and management of risk. These functions influence savings and investment decisions as well as technological innovations and, hence, economic growth.

The liquidity transformation channel transmits the effects of the activities of the secondary segment of the capital market to the real sector of the economy by making existing securities change hands over and over again. As such, Adenuga (2010) expressed that, capital market contributes to economic development by enhancing the liquidity of capital investments. Many profitable investments require a long-term commitment of capital but investors are often reluctant to relinquish control of their savings for long periods. Liquid equity markets make investments less risky and more attractive- because they allow savers to acquire an asset -equity- and to sell it quickly and cheaply if they need access to their savings or want to alter their portfolios. This expression hinges the financial intermediation function of the capital market on its liquidity-creation and maturity intermediation capabilities. Also, Mishra, Mishra, Mishra and Mishra (2010) pointed out that, underdeveloped orpoorly functioning capital markets typically are illiquid and expensive, which deters foreign investors. Furthermore, illiquidity and high transactions costs also hinder the capital raising efforts of larger domestic enterprises and may push them to foreign markets.

The wealth creation channel transmits impulses of the returns generated or income earned by both the surplus and deficit units, from the intermediation function of the capital market, to the real sector of the economy. To Otiti (2007), the capital market plays a key role in the economic growth and development of any modern economy. It provides avenue for firms and government to raise funds to finance their needs. For individual investors, the capital market provides a strong opportunity for wealth acquisition. This assertion hinges the capital market-economic growth relationship on the wealth creation capacity of the capital market that moves both the savers and borrowers close to utility maximization. Similarly, Muritala and Ogunji (2017) stated that, the Nigerian capital market provides the necessary lubricant to keep turning the wheel of the economy. Notonly does it provide the funds required for investment, but it also efficiently allocates these funds to projects of best returns to fund owners.

The efficiency channel transmits the effects of the general capital market performance to the real sector of the 


\section{“Capital Market Transmission Channels and Real Sector Performance in Nigeria (1984-2016): Implications for Economic Growth"}

economy for the achievement of economic growth. In relation to this, Mishra et al(2010) stated that, economic growth in a modern economy hinges on an efficient financial sector that pools domestic savings and mobilizes foreign capital for productive investments. Adekunle, Alalade and Okulenu(2016) also noted that, capital market is the major components of a modern, market-based economic system, as it serves as the channel for the flow of long-term financial resources from the savers of capital to the borrowers of capital. Efficient capital markets, are, hence essential for economic growth and prosperity; thus, a rising capital market is an indicator of an expanding economy.

Consequently, the roles of a capital market in the growth and development of an economy cannot be overemphasized. Based on its importance in accelerating economic growth and development, government of most nations tends to have keen interest in the performance of its capital market. The concern is for sustained confidence in the market and for a strong investors' protection arrangement (Briggs, 2015). This is due to the fact that, the capital market is a cornerstone of every financial system since it provides the funds needed for financing not only business and other economic institutions, but alsothe government's programmes in general (Muritala \& Ogunji, 2017). Thus, capital market is the channel through which medium to long-term capital projects of listed companies and development projects of governments are financed. This accounts for why Muritala and Ogunji (2017) further stated that, the market is vital to the growth and development of any country because it supports government and corporate initiatives, which finance the exploitation of new ideas and facilitate the management of financial risk. This position sees the capital market as being essential to the smooth running and proper functioning of the economy, as it supplies the necessary capital funds needed for productive investments in the most economic and suitable manner.

Nevertheless, economic growth is an increase in a country's productive potential measured by an increase in its real GDP. Gross Domestic Product (GDP) is the total value of goods and services produced in a country in one year real GDP has been adjusted for inflation. GDP is measured in monetary terms, and inflation will raise the value of GDP. Such an increase is not true economic growth. Economic growth in the economy occurs when the real level of GDP rises as a result of increases in the physical output of goods and services in an economy (Stimpson\&Farquharson, 2015). This argument stresses the fact that, increase in GDP which is enhanced by inflation does not qualify for economic growth.

\section{Theoretical Framework}

This work was based on the theoretical threshold of endogenous growth model. Endogenous growth or new growth theory emerged in the 1990s to explain the poor performance of many less developed countries, which have implemented policies as prescribed in neo-classical theories. Unlike Solow model that considers technological change as an exogenous factor, the new growth model notes that, technological change has not been equal nor has it been exogenously transmitted in most developing countries (World Bank, 2000). Notably, the endogenous growth theory is an extension of the McKinnon-Shaw (1973) financegrowth hypothesis, as it developed a theoretical framework for the explanation of the link between capital market and economic growth.

The Solow model has showed that, persistent growth must come from technical progress but not savings. Thus, savings can only stimulate growth temporarily, but diminishing returns to capital will eventually set in as the economy converges on its steady state, where growth can only be stimulated by technical progress (Rolle \& Uffie, 2015). The Basic Solow model came under heavy criticism that, the model could not account for cross country differences in per capita income. This shifted the tide in favour of the endogenous growth model initiated by Romer in 1988. The endogenous model unlike the neoclassical growth model disagreed that, technical progress is exogenous and went further to concentrate on the factors that can cause technical progress (Rolle \&Uffie, 2015). Romer (1990) remarked that, technical progress is the outcome of knowledge accumulation. This process is considered to be the core element that drives economic growth in the long-run, and it is an endogenous factor.

According to Olweny and Kimani (2011), Bencivenga and Smith, and Levine were among the first to propose endogenous growth models to identify the channels through which financial markets affect long-run economic growth. The two papers emphasized that, financial markets help diversify agents' liquidity and investment risk, attract more savings into productive investments and prevent the premature withdrawal of physical capital invested in the long-term projects. Consequently, the existence of financial markets means that, more capital can be kept in productive investments, which, in the end, raises the rate of economic growth. However, Yadirichukwu and Chigbu (2014) noted that, the Mckinnon-Shaw hypothesis became formalised and popularised through the endogenous growth models of Fry 1988, Greenwood and Jovanovic 1990, and Pagano 1993, which specify explicitly the modelling of the link between financial intermediation role of capital markets and growth indicators. The models have identified the capital market as an institution that contributes to the economic growth of emerging economies, and also a variable in explaining the economic growth in the most-developed ones.

At any rate, studies involved in the formulation, development and advancement of the endogenous growth theory include those of Fry (1988), Greenwood and Jovanovic (1990), Bencivenga and Smith (1991), Levine (1991), King and Levine (1993), Pagano (1993), Levine and Zervos (1996), Beck, Levine and Loayza (2000), Benhabib 


\section{“Capital Market Transmission Channels and Real Sector Performance in Nigeria (1984-2016): Implications for Economic Growth"}

and Spiegel (2000), and Easterly and Levine (2001). As the fact speaks for itself, the most prominent of these works is Levine's. Essentially, Levine (1991) stated that, with recent revival of interest in the link between financial development and economic growth arises the insight of endogenous growth models, in which growth is self-sustaining without exogenous technical progress, and is influenced by the various initial attributes of the economy. Further to this, Levine (1991) presented two key arguments on how stock exchanges speed up the economic growth. The first is by making property changes possible in the companies, whilst not affecting their productive process; the second is by offering higher possibilities of portfolio diversification to the agents.

In the same vein, King and Levine (1993) argued that, capital markets play a critical role in the processing of information. The ability of financial institutions to select profitable innovations and projects that increase productivity and, hence, growth was seen as the key contribution of capital markets to economic development. Also, Levine and Zervos (1996) established a positive link between financial system (i.e. financial development) and economic growth. Further to these, Beck, Levine and Loayza (2000), and Benhabib and Spiegel (2000) examined the relationship between financial intermediary development and economic growth using a cross country methodology for a two group of countries at world-wide level. The studies found that, financial intermediation has positive impact on economic growth through any of total factor productivity (TFP), investment, physical capital accumulation, and lower savings rate. To Easterly and Levine (2001), total factor productivity (TFP) is the residual change in output not accounted for by increases in all factor inputs.

In line with the previous assertions, Edame and Okoro (2013) gave the relevance of capital markets to economic growth as follows: First, capital market development increases the proportion of savings that is funnelled to investments. Second, capital market development may change the savings rate and, hence, affect investments. Third, capital market developmentincreases the efficiency of capital allocation. These points can be circumscribed into savings-investment transformation between capital market and the economy, such that the savings mobilized by the capital market are efficiently transformed into productive investment by the different sectors of the economy.Based on these postulations and assertions, Nwaolisa, Kasie and Egbunike (2013) submitted that, the capital market, no doubt, is pivotal to the level of growth and development of the economy. Also, Ayodeji and Ajala (2018)advanced the capital market economic significance theorem, stating that, all-share index, market capitalization, stock market turnover and value of transactions would exert significant positive effects on economic growth, as they respectively measure efficiency, funds-mobilization, liquidity and wealth creation capacity of the capital market.

\section{Empirical Review}

Caporaleet al (2004) investigated the causal relationship between stock market and economic growth within a time dimension 1977-1998, covering four quarters in each year for a sample of selected seven countries, comprising Argentina, Chile, Greece, Korea, Malaysia, the Philippines and Portugal. The study proxied economic growth by gross domestic product in levels; it also proxied stock market development by market capitalization ratio and value traded ratio. However, bank development variables were used as control variables; these are bank deposit liabilities to nominal GDP, and ratio of bank claims on the private sector to nominal GDP. The study sourced time-series data on stock market development variables from Emerging Markets Data Base (EMDB (1998)), and on financial development from International Monetary Fund (IMF) international financial statistics (1998).The study employed vector auto regression as the estimation technique, and found a significant positive relationship and evidence of causal relationship between stock market development and economic growth.

In the same vein, Vazakidis and Adamopoulos (2009) tested the causal relationship between stock market development and economic growth in France between 1965 and 2007. The study proxied the dependent variable, stock market development, by general stock market index, and the independent variable, economic growth by gross domestic product and interest rate. It sourced time-series data, with respect to these variables, from the International Financial Statistics (IFS) year book, and estimated them using Johansen co-integration test, vector error correction model and Pair-wise Granger causality test. The study found a significant long-run relationship between stock market development and economic growth in France. It, also, found a unidirectional causal relationship between economic growth and stock market development with direction from the former to the latter, a bidirectional causality between interest rate and stock market development, and a unidirectional causality between economic growth and interest rate, running from the former to the latter.

Akinlo and Akinlo (2009) studied the long-run relationship between stock market development and economic growth in seven of the Sub-Saharan African countries. The study proxied stock market development by market size, and economic growth by gross domestic product. Using AutoRegressive Distributed Lag (ARDL) bounds testing approach and Granger causality test, it found that, stock market had a significant positive impact on economic growth. It, also, found a unidirectional causal relationship from stock market development to economic growth for both South Africa and Egypt, but a bidirectional causality for Cote D'Ivoire, Kenya, Morocco and Zimbabwe; however, Nigeria, showed weak evidence that growth causes finance. 


\section{“Capital Market Transmission Channels and Real Sector Performance in Nigeria (1984-2016): Implications for Economic Growth"}

Similarly, Olweny and Kimani (2011) investigated the effects of stock market performance on economic growth in Kenya, within the time dimension 2001-2010. The study proxied economic growth by rate of growth in real gross domestic product, and proxied stock market performance by stock market index (i.e. NSE 20-share index) and consumer price index. It employed time-series data, with respect to these proxies, and analyzed them using Johansen cointegration test, vector auto regression and granger causality test. The study found a long-run relationship between stock market performance and economic growth in Kenya. It, also, found a unidirectional causality between stock market performance and economic growth in Kenya, running from all-share index to gross domestic product, that is, stock market performance to economic growth.

Dabo (2015) examined the impact of capitalization of capital market on economicgrowth in Nigeria within a temporal scope of 2001-2012. The study proxied the dependent variable, economic growth, by gross domestic product, and the independent variable, capital market, by market capitalization, total new issues, total value of transactions, bank total assets, and listed equities and government stocks. With respect to these proxies, it sourced time-series data from Central Bank of Nigeria (CBN) statistical bulletins, annual reports and accounts of Nigerian Stock Exchange and of consolidated banks. The study employed Granger causality test and regression analysis, and found a unidirectional causal relationship between capital market capitalisation and economic growth, running from the latter to the former. It, also, found strong systematic variations in the five proxies of capital market.

Further to this, Anigbogu and Nduka (2014) examined the relationship between stock market performance and economic growth in Nigeria within the time frame 1987-2012. The study used real gross domestic product to proxy economic growth; and to proxy stock market performance, it used inflation, investment ratio, turnover ratio, total value of shares, traded ratio, market capitalization, capital flows and banking sector development. It employed time-series data, and estimated them using Johansen Maximum Likelihood co-integration test, vector error correction model (i.e. restricted VAR), and granger causality test. It found that, a long-run relationship exists between stock market performance and economic growth in Nigeria. It,, also found a bi-directional causality between stock market performance and economic growth in Nigeria, running from the former to the latter, and the latter to the former as a two-way causality. It, further, found that, shocks from the stock market did not impede economic growth in Nigeria; however, the Nigerian stock market was not stable.

Also, Taiwo, Alaka and Afieroho (2016) assessed the effects of capital market on economic growth in Nigeria between 1981 and 2014. The study proxied the dependent variable, economic growth, by real gross domestic product, and capital market by stock market capitalization, savings accumulation, gross fixed capital formation, total listed securities, and active labour force participation. In relation to these proxies, it employed time-series data, which are sourced from Central Bank of Nigeria (CBN) statistical bulletin of 2014, CBN annual reports and accounts of various editions, Nigerian Stock Exchange (NSE) books, and Securities and Exchange Commission (SEC) market bulletins. The study employed Johansen co-integration test and vector error correction model (i.e. restricted VAR) in estimating the data, and found a positive contribution of capital market to economic growth in Nigeria. It, also, found a long-run equilibrium relationship between capital market variables and economic growth in Nigeria.

\section{Methodology}

The study formulated a model which captures the basic transmission channels of capital market impulses in relation to the real sector of the economy. This is based on the endogenous growth theory, which is a finance-growth theory that was supported by the capital market economic significance theorem of Ayodeji and Ajala (2018). The model is given by:

$$
\mathrm{GDP}=\mathrm{f}(\mathrm{EC}, \mathrm{SIC}, \mathrm{LTC}, \mathrm{WCC}) \text {. }
$$

This portends that, gross domestic product, which is the proxy for real sector performance and/ or economic growth, is a function of, or is dependent on the four basic transmission channels of the capital market impulses.

Essentially, the econometric form of the model is as given below:

$\mathrm{GDP}=\beta \mathrm{o}+\beta_{1} \mathrm{EC}+\beta_{2} \mathrm{SIC}+\beta_{3} \mathrm{LTC}+\beta_{4} \mathrm{WCC}+\mu \ldots \ldots \ldots$ (2) Where: GDP = Gross Domestic Product; EC = Efficiency Channel; SIC = Savings-Investment Channel; LTC = Liquidity Transformation Channel; and WCC = Wealth Creation Channel.

Using capital market performance indicators as direct proxies, Efficiency Channel was proxied by All-Share Index (ASI), Savings-Investment Channel was proxied by Market Capitalization (MCAP) and Number of Listed Equities (NLE), Liquidity Transformation Channel was proxied by Number of Deals (NOD) and Stock Market Turnover (SMT), and Wealth Creation Channel was proxied by Value of Deals (VOD) and Value of Transactions (VTRAN).Thus, the econometric model can be restated as: $\mathrm{GDP}=\beta \mathrm{o}+\beta_{1} \mathrm{ASI}+\beta_{2} \mathrm{MCAP}+\beta_{3} \mathrm{NLE}+\beta_{4} \mathrm{NOD}+\beta_{5} \mathrm{SMT}$ $+\beta_{6}$ VOD $+\beta_{7}$ VTRAN $+\mu$

Arising from the theoretical anchor of this study, a significant positive relationship was expected between capital market transmission channels or, better still, capital market performance indicators, and economic growth; hence, capital market variables were expected to transmit positive impulses to the real sector of the economy to engender economic growth. Also, the finance-growth theory (i.e. endogenous growth theory) is suggestive of growth induced by capital market performance; therefore, capital 
market transmission channels were expected to grangercause economic growth.

Subsequent to these, the study sourced secondary data from the capital market bulletins of the Nigerian Securities and Exchange Commission, and the annual reports and accounts of the Nigerian Stock Exchange. Then, Augmented Dickey Fuller (ADF) test was used to investigate the stationarity of the variables in the series as a preliminary test. However, to test the first hypothesis, Vector Auto Regression (VAR) approach was employed, considering VAR coefficients, impulse response function, and variance decomposition error, while VAR Granger causality test was used to test the second hypothesis.

In this study, the modified model, for using vector auto regression, is stated below:

$\mathbf{G d p}=\lambda_{1}+\alpha_{11} \sum \mathrm{Gdp}_{\mathrm{t}-1}+\alpha_{12} \sum \mathrm{Asi}_{\mathrm{t}-1}+\alpha_{13} \sum$ Mcap $_{\mathrm{t}-1}+$ $\alpha_{14} \sum$ Nle $_{\mathrm{t}-1}+\alpha_{15} \sum$ Nod $_{\mathrm{t}-1}+\alpha_{16} \sum \mathrm{Smt}_{\mathrm{t}-1}+\alpha_{17} \sum \operatorname{Vod}_{\mathrm{t}-1}+$ $\alpha_{18} \sum \operatorname{Vtran}_{\mathrm{t}-1}+\varepsilon_{1}$

$\mathbf{A s i}=\lambda_{2}+\alpha_{11} \sum \mathrm{Gdp}_{\mathrm{t}-1}+\alpha_{12} \sum \mathrm{Asi}_{\mathrm{t}-1}+\alpha_{13} \sum$ Mcap $_{\mathrm{t}-1}+$ $\alpha_{14} \sum$ Nle $_{\mathrm{t}-1}+\alpha_{15} \sum$ Nod $_{\mathrm{t}-1}+\alpha_{16} \sum \mathrm{Smt}_{\mathrm{t}-1}+\alpha_{17} \sum \operatorname{Vod}_{\mathrm{t}-1}+$ $\alpha_{19} \sum \operatorname{Vtran}_{\mathrm{t}-1}+\varepsilon_{2}$

Mcap $=\lambda_{3}+\alpha_{21} \sum \mathrm{Gdp}_{\mathrm{t}-1}+\alpha_{22} \sum \mathrm{Asi}_{\mathrm{t}-1}+\alpha_{23} \sum$ Mcap $_{\mathrm{t}-1}+$ $\alpha_{24} \sum$ Nle $_{\mathrm{t}-1}+\alpha_{25} \sum$ Nod $_{\mathrm{t}-1}+\alpha_{26} \sum \mathrm{Smt}_{\mathrm{t}-1}+\alpha_{27} \sum \operatorname{Vod}_{\mathrm{t}-1}+$ $\alpha_{28} \sum \operatorname{Vtran}_{\mathrm{t}-1}+\varepsilon_{3}$

Nle $=\lambda_{4}+\alpha_{31} \sum \mathrm{Gdp}_{\mathrm{t}-1}+\alpha_{32} \sum \mathrm{Asi}_{\mathrm{t}-1}+\alpha_{33} \sum$ Mcap $_{\mathrm{t}-1}+$ $\alpha_{34} \sum$ Nle $_{\mathrm{t}-1}+\alpha_{35} \sum$ Nod $_{\mathrm{t}-1}+\alpha_{36} \sum \mathrm{Smt}_{\mathrm{t}-1}+\alpha_{37} \sum \operatorname{Vod}_{\mathrm{t}-1}+$ $\alpha_{39} \sum \operatorname{Vtran}_{\mathrm{t}-1}+\varepsilon_{4}$

Nod $=\lambda_{5}+\alpha_{41} \sum G d p_{\mathrm{t}-1}+\alpha_{42} \sum$ Asi $_{\mathrm{t}-1}+\alpha_{43} \sum$ Mcap $_{\mathrm{t}-1}+$ $\alpha_{44} \sum$ Nle $_{\mathrm{t}-1}+\alpha_{45} \sum$ Nod $_{\mathrm{t}-1}+\alpha_{46} \sum \mathrm{Smt}_{\mathrm{t}-1}+\alpha_{47} \sum \operatorname{Vod}_{\mathrm{t}-1}+$ $\alpha_{48} \sum \operatorname{Vtran}_{\mathrm{t}-1}+\varepsilon_{5}$

Table 1. Summary of Augmented Dickey Fuller Test Results

At level

\begin{tabular}{|c|c|c|c|c|c|c|c|c|c|}
\hline Var & ADF & Critical-t & Lag & P-Value & ADF & Critical- V & Lag & P-Value & Comment \\
\hline LGDP & -1.316 & -2.9571 & 2 & 0.6099 & -5.2781 & -2.9604 & 2 & 0.0001 & $\mathrm{I}(1)$ \\
\hline LMCAP & -1.4799 & -2.9639 & 2 & 0.5298 & -4.064 & -2.9677 & 2 & 0.0039 & $\mathrm{I}(1)$ \\
\hline LASI & -2.5204 & -2.9571 & 2 & 0.1202 & -3.9423 & -2.9604 & 2 & 0.005 & $\mathrm{I}(1)$ \\
\hline LVOD & -9.722 & -2.6174 & 2 & 0.7511 & -4.4893 & -2.9604 & 2 & 0.0012 & $\mathrm{I}(1)$ \\
\hline LVTRAN & -1.6042 & -2.9571 & 2 & 0.4689 & -5.8938 & -2.9604 & 2 & 0.0000 & $\mathrm{I}(1)$ \\
\hline LNLE & -2.4425 & -2.9604 & 2 & 0.139 & -4.0391 & -3.5628 & 2 & 0.017 & $\mathrm{I}(1)$ \\
\hline SMT & -2.01476 & -2.9604 & 2 & 0.2793 & -5.7035 & -2.9604 & 2 & 0.0001 & $\mathrm{I}(1)$ \\
\hline NOD & -2.1507 & -2.9762 & 2 & 0.2276 & -6.6632 & -2.9762 & 2 & 0.0000 & $\mathrm{I}(1)$ \\
\hline
\end{tabular}

Source: Author's Computation, 2018

\section{Vector Auto-Regression (VAR)}

In order to investigate the channels through which capital market impulses are transmitted to the real sector of the economy in Nigeria, the study employed Vector Auto Regression (VAR). Before the application of this technique, it was necessary to select the optimum lag order that will give good results. This was done by choosing the least results of Akaike Information Criterion (AIC). The thrust behind this is that, the lower the AIC, the better the model. However, considering the limited length of the data series, a
Smt $=\lambda_{6}+\alpha_{51} \sum$ Gdp $_{\mathrm{t}-1}+\alpha_{52} \sum \mathrm{Asi}_{\mathrm{t}-1}+\alpha_{53} \sum$ Mcap $_{\mathrm{t}-1}+$ $\alpha_{54} \sum \mathrm{Nle}_{\mathrm{t}-1}+\alpha_{55} \sum \operatorname{Nod}_{\mathrm{t}-1}+\alpha_{56} \sum \mathrm{Smt}_{\mathrm{t}-1}+\alpha_{77} \sum \operatorname{Vod}_{\mathrm{t}-1}+$ $\alpha_{58} \sum \operatorname{Vtran}_{\mathrm{t}-1}+\varepsilon_{6}$

$\operatorname{Vod}=\lambda_{7}+\alpha_{61} \sum \mathrm{Gdp}_{\mathrm{t}-1}+\alpha_{62} \sum \mathrm{Asi}_{\mathrm{t}-1}+\alpha_{63} \sum$ Mcap $_{\mathrm{t}-1}+$ $\alpha_{64} \sum \mathrm{Nle}_{\mathrm{t}-1}+\alpha_{65} \sum \mathrm{Nod}_{\mathrm{t}-1}+\alpha_{66} \sum \mathrm{Smt}_{\mathrm{t}-1}+\alpha_{67} \sum \operatorname{Vod}_{\mathrm{t}-1}+$ $\alpha_{68} \sum \operatorname{Vtran}_{\mathrm{t}-1}+\varepsilon_{7}$

Vtran $=\lambda_{9}+\alpha_{71} \sum \mathrm{Gdp}_{\mathrm{t}-1}+\alpha_{72} \sum \mathrm{Asi}_{\mathrm{t}-1}+\alpha_{73} \sum$ Mcap $_{\mathrm{t}-1}+$ $\alpha_{74} \sum$ Nle $_{\mathrm{t}-1}+\alpha_{75} \sum \mathrm{Nod}_{\mathrm{t}-1}+\alpha_{76} \sum \mathrm{Smt}_{\mathrm{t}-1}+\alpha_{77} \sum \operatorname{Vod}_{\mathrm{t}-1}+$ $\alpha_{78} \sum \operatorname{Vtran}_{\mathrm{t}-1}+\varepsilon_{8}$

Where: $\lambda_{1}, \lambda_{2} \ldots \lambda_{9}$ are the constant terms; $\beta_{11} \ldots \beta_{78}$ are the parameters of the variables to be estimated; $\varepsilon_{1}, \varepsilon_{2}, \varepsilon_{3} \ldots \varepsilon_{8}$ are random innovations

\section{Results and Findings}

\section{Augmented Dickey Fuller (ADF) Test for Stationarity}

In order to test for the presence of unit roots in the series, the study employed Augmented Dickey Fuller (ADF) test. Results, as contained in Table 1, below, showed that, at $5 \%$ level of significance, all the variables in the series were stationary at first difference. This is due to the fact that, their respective p-values are less than 0.05 at first difference. Accordingly, the null hypothesis of the ADF test of 'no stationarity' was rejected. This was based on MacKinnon (1996) critical values; and, in relation to Schwartz Information Criterion (SIC), the lag length was selected, which ranges from lag 0 to lag 2 . maximum length, lag of two, was permitted in the selection of the optimum lag length to be used in the estimation of VAR in this study. The Akaike Information Criterion (AIC) was employed for the VAR lag order selection, as it has the least value at lag two as shown in Table 2, below. This table shows that, the Akaike Information Criterion (AIC) values are: Lag 0 (16.25008), Lag 1 (5.987685), and Lag 2 (2.864908). Since Lag 2 has the least AIC value, it was selected as the optimum lag order for the model. 
Table 2. Summary of Lag Order Selection Results

\begin{tabular}{|c|c|c|c|c|c|c|}
\hline Lag & LogL & LR & FPE & AIC & SC & HQ \\
\hline 0 & -227.6261 & NA & 0.001576 & 16.25008 & 16.62726 & 16.36820 \\
\hline 1 & -14.82144 & 293.5237 & $6.52 \mathrm{e}-08$ & 5.987685 & 9.382351 & 7.050852 \\
\hline 2 & 94.45884 & $90.43885^{*}$ & $9.54 \mathrm{e}-09 *$ & $2.864908^{*}$ & $9.277054^{*}$ & $4.873112^{*}$ \\
\hline
\end{tabular}

Source: Author's Computation, 2018

Furthermore, Table 3, below, shows the summary of the VAR estimation at lag (-2). From the displayed results, it was discovered that, the dependent variable, gross domestic product, exerteda negative effect on itself -1.0258 (This is a negative own innovation). Also, all-share index, number of deals, and stock market turnover had negative effects on gross domestic product with their respective values of $0.3303,-0.1745$ and -0.0213 . The implication of these is that, a unit increase in all-share index, number of deals and stock market turnoverwill produce a decrease in gross domestic product, though in different proportions, as a unit increase in all-share index will produce $33.03 \%$ decrease in gross domestic product and vice-versa. Also, a unit increase in number of deals will produce $17.45 \%$ decrease in gross domestic product and vice-versa, and a unit increase in stock market turnover will produce $2.13 \%$ decrease in gross domestic product and vice-versa.

However, number of listed equities, value of deals and value of transactions exerted positive effects on gross domestic product with their respective values of 1.5835 , 0.0106 and 0.0643. By implication, a unit increase in number of listed equities, value of deals and value of transactions will bring about an increase in gross domestic product, though in different proportions, as a unit increase in number of listed equities will bring about more than a unit increase in gross domestic product and vice-versa (1.5835 > 1). Also, a unit increase in value of deals will bring about less than a unit increase in gross domestic product and viceversa $(0.0106<1)$, and a unit increase in value of transactions will bring about less than a unit increase in gross domestic product and vice-versa $(0.0643<1)$.

Specifically, when market capitalization was used as the dependent variable, the following were the resulting effects: Gross domestic product exerted a negative effect on market capitalization with a value of -0.4749 . Also, all-share index, number of deals, value of transactions and stock market turnover had negative effects on market capitalization with their respective values of -0.4640 , $0.0145,-0.1783$ and -0.0126 . However, market capitalization had a positive effect on itself with a value of 0.5611 . Not only that, number of listed equities and value of deals exerted positive effects on market capitalization with their respective values of 5.665 and 0.3270 . This implies that, a unit increase in gross domestic product, all-share index, number of deals, value of transactions, and stock market turnover will lead to a decrease in market capitalization and vice versa, though in different proportions, while a unit increase in number of listed equities and value of deals will lead to an increase in market capitalization and vice versa, though in different proportions.

In the same manner, when all-share index was used as the dependent variable, gross domestic product, number of deals, value of transactions and stock market turnover had negative effects on it with their respective values of -0.1229 , $-0.1020,-0.2221$ and -0.0077 . Also, all-share index exerted negative innovation on itself with a value of -0-3064. However, market capitalization, number of listed equities and value of deals exerted positive effects on all-share index with their respective values of $0.3486,5.0196$ and 0.3228 . The implication of this is that, a unit increase in own innovation, gross domestic product, number of deals, value of transactions and stock market turnover will produce a decrease in all-share index and vice-versa, though in different proportions, while a unit increase in market capitalization, number of listed equities and value of deals will produce an increase in all-share index and vice-versa, though in different proportions.

Moreover, when number of listed equities was used as the dependent variable, gross domestic product, all-share index, value of deals, value of transactions and stock market turnover exerted negative effects on it with their respective values of $-0.0349,-0.3064,-0.0056,-0.0009$ and -0.0003 . Nonetheless, number of listed equities had positive effect on itself. Number of deals also exerted positive effect on number of listed equities with a value of 0.0240 while other capital market indicators exerted negative effects on it. This implies that, only number of deals exerted a positive influence on number of listed equities out of all the capital market indicators employed in the model. Accordingly, a unit increase in number of deals will lead to less than a unit increase (specifically $2.4 \%$ increase) in number of listed equities and vice-versa.

Similarly, when number of deals was taken as the dependent variable, gross domestic product, market capitalization, number of listed equities, and value of deals exerted positive effects on it with their respective values of $0.0534,0.8099,2.4886$, and 0.1039 . Also, number of deals exerted positive innovation on itself with a value of 0.2560 . However, all-share index, value of transactions and stock market turnover exerted negative effects on number of deals with their respective values of $-1.1408,-0.2485$ and-0.0085. This means that, a unit increase in own innovation, gross domestic product, market capitalization, number of listed equities, and value of deals will bring about an increase in 
number of deals and vice-versa, though in different proportions, while a unit increase in all-share index, value of transactions and stock market turnover will bring about a decrease in number of deals, though in different proportions.

Furthermore, when value of deals was used as the dependent variable, gross domestic product exhibited a negative effect on it with a value of -1.00368 . Likewise, allshare index, number of deals, value of transactions, and stock market turnover exerted negative effects on value of deals with their respective values of $-0.7980,-1.0978$, 0.0260 and -0.0174 . However, market capitalization, and number of listed equities exerted positive effects on value of deals with their respective values of 1.1084 and 2.3218 . Also, value of deals exerted positive innovation on itself with a value of 0.8114 . This implies that, a unit increase in gross domestic product, all-share index, number of deals, value of transactions and stock market turnover will produce a decrease in value of deals and vice versa, though in different proportions, while a unit increase in own innovation, market capitalization, and number of listed equities will produce an increase in value of deals and vice versa, though in different proportions.

Also, when value of transactions was used as the dependent variable, gross domestic product, market capitalization and all-share index exerted negative effects on it with their respective values of $-1.2805,-0.3953$ and 0.1602. Also, value of transactions exerted a negative innovation on itself with a value of -0.1935 . Nonetheless, number of listed equities, number of deals, value of deals, and stock market turnover had positive effects on value of transactions with their respective values of 9.9138, 0.8736, 1.0606 and 0.0144 . This implies that, a unit increase in own innovation, gross domestic product, market capitalization, and all-share index will bring about a decrease in value of transactions, though in different proportions, while a unit increase in number of listed equities, number of deals and value of deals will bring about an increase in value of transactions and vice versa, though in different proportions.
Lastly, when stock market turnover was taken as the dependent variable, gross domestic product, number of listed equities, number of deals, and value of deals exerted positive effects on it with their respective values of 14.0683, 132.9395, 5.1304 and 6.4492. Also, stock market turnover exerted positive innovation on itself with a value of 0.1310 . However, market capitalization, all-share index, and value of transactions exerted negative effects on stock market turnover with their respective values of $-10.9574,-2.9874$ and -6.3199. By implication, a unit increase in own innovation, gross domestic product, number of listed equities, number of deals, and value of deals will lead to an increase in stock market turnover and vice versa, though in different proportions, while a unit increase in market capitalization, all-share index, and value of transactions will lead to a decrease in stock market turnover and vice versa, though in different proportions.

Considering the coefficient of determination $\left(\mathrm{R}^{2}\right)$ of the individual capital market indicators, Table3, below, shows the following R-squared results: value of transactions $(85.56 \%)$, market capitalization $(70.50 \%)$, all-share index $(67.58 \%)$, value of deals $(64.00 \%)$, number of listed equities $(56.63 \%)$, number of deals $(48.07 \%)$, and stock market turnover $(41.51 \%)$. By this, value of transactions, market capitalization, all-share index, and value of deals are reliable inducers or determinants of real sector performance and/ or economic growth in Nigeria, as they have above average Rsquared values. However, number of deals $(48.07 \%)$ and stock market turnover $(41.51 \%)$ are not reliable inducers of real sector performance and/ or economic growth in Nigeria, as they have below average R-squared values, though greater than $40 \%$. On the whole, the capital market indicators employed in the model are reliable determinants of real sector performance and/ or economic growth in Nigeria, as the results show a clear indication of strong relationship between the variables of interest.

Table 3. Summary of Vector Auto Regression Coefficients

\begin{tabular}{|l|c|c|c|c|c|c|c|c|}
\hline & DLGDP & DLMCAP & DLASI & DLNLE & DLNOD & DLVOD & DLVTRAN & DSMT \\
\hline DLGDP(-2) & -1.025803 & -0.474956 & -0.122926 & -0.034928 & 0.053472 & -1.00368 & -1.28051 & 14.06831 \\
\hline & $(0.33427)$ & $(0.65282)$ & $(0.69044)$ & $(0.11771)$ & $(1.14721)$ & $(1.15465)$ & $(1.47766)$ & $(27.2648)$ \\
\hline & {$[-3.06878]$} & {$[-0.72754]$} & {$[-0.17804]$} & {$[-0.29673]$} & {$[0.04661]$} & {$[-0.86925]$} & {$[-0.86658]$} & {$[0.51599]$} \\
\hline DLMCAP(-2) & 0.881638 & 0.561147 & 0.348593 & 0.060544 & 0.809932 & 1.108417 & -0.39537 & -10.9574 \\
\hline & $(0.44057)$ & $(0.86042)$ & $(0.91000)$ & $(0.15514)$ & $(1.51203)$ & $(1.52183)$ & $(1.94756)$ & $(35.9351)$ \\
\hline & {$[2.00113]$} & {$[0.65218]$} & {$[0.38307]$} & {$[0.39025]$} & {$[0.53566]$} & {$[0.72834]$} & {$[-0.20301]$} & {$[-0.30492]$} \\
\hline DLASI(-2) & -0.3303 & -0.464042 & -0.306459 & -0.028512 & -1.14087 & -0.79802 & -0.16028 & -2.98747 \\
\hline & $(0.35246)$ & $(0.68834)$ & $(0.72800)$ & $(0.12412)$ & $(1.20962)$ & $(1.21747)$ & $(1.55805)$ & $(28.7481)$ \\
\hline & {$[-0.93713]$} & {$[-0.67415]$} & {$[-0.42096]$} & {$[-0.22972]$} & {$[-0.94316]$} & {$[-0.65548]$} & {$[-0.10287]$} & {$[-0.10392]$} \\
\hline DLNLE(-2) & 1.583545 & 5.665045 & 5.019602 & 0.307397 & 2.488521 & 2.321839 & 9.913828 & 132.9395 \\
\hline & $(1.10634)$ & $(2.16066)$ & $(2.28516)$ & $(0.38959)$ & $(3.79695)$ & $(3.82156)$ & $(4.89064)$ & $(90.2389)$ \\
\hline & {$[1.43133]$} & {$[2.62191]$} & {$[2.19660]$} & {$[0.78903]$} & {$[0.65540]$} & {$[0.60756]$} & {$[2.02710]$} & {$[1.47320]$} \\
\hline DLNOD(-2) & -0.174566 & -0.014521 & -0.102011 & 0.024094 & 0.256019 & -0.10978 & 0.873635 & 5.130427 \\
\hline & $(0.13049)$ & $(0.25483)$ & $(0.26952)$ & $(0.04595)$ & $(0.44782)$ & $(0.45073)$ & $(0.57682)$ & $(10.6430)$ \\
\hline
\end{tabular}


“Capital Market Transmission Channels and Real Sector Performance in Nigeria (1984-2016): Implications for Economic Growth"

\begin{tabular}{|l|c|c|c|c|c|c|c|c|} 
& {$[-1.33782]$} & {$[-0.05698]$} & {$[-0.37849]$} & {$[0.52435]$} & {$[0.57170]$} & {$[-0.24356]$} & {$[1.51458]$} & {$[0.48205]$} \\
\hline DLVOD(-2) & 0.010668 & 0.327085 & 0.322811 & -0.005673 & 0.103978 & 0.181477 & 1.060637 & 6.449265 \\
\hline & $(0.11051)$ & $(0.21583)$ & $(0.22827)$ & $(0.03892)$ & $(0.37928)$ & $(0.38174)$ & $(0.48853)$ & $(9.01409)$ \\
\hline & {$[0.09653]$} & {$[1.51547]$} & {$[1.41418]$} & {$[-0.14578]$} & {$[0.27414]$} & {$[0.47539]$} & {$[2.17106]$} & {$[0.71547]$} \\
\hline DLVTRAN(-2) & 0.064313 & -0.178308 & -0.222164 & -0.000989 & -0.248524 & -0.02608 & -0.1935 & -6.31992 \\
\hline & $0.10438)$ & $(0.20386)$ & $(0.21561)$ & $(0.03676)$ & $(0.35824)$ & $(0.36057)$ & $(0.46143)$ & $(8.51405)$ \\
\hline & {$[0.61612]$} & {$[-0.87466]$} & {$[-1.03042]$} & {$[-0.02690]$} & {$[-0.69373]$} & {$[-0.07234]$} & {$[-0.41935]$} & {$[-0.74229]$} \\
\hline DSMT(-2) & -0.021371 & -0.012638 & -0.00777 & -0.000314 & -0.008573 & -0.0174 & 0.014434 & 0.131021 \\
\hline & $0.00865)$ & $(0.01689)$ & $(0.01786)$ & $(0.00305)$ & $(0.02968)$ & $(0.02987)$ & $(0.03823)$ & $(0.70541)$ \\
\hline & {$[-2.47110]$} & {$[-0.74827]$} & {$[-0.43495]$} & {$[-0.10296]$} & {$[-0.28884]$} & {$[-0.58254]$} & {$[0.37756]$} & {$[0.18574]$} \\
\hline C & 0.238771 & 0.081919 & 0.017716 & 0.006108 & -0.030487 & 0.071987 & 0.111743 & -4.00866 \\
\hline & $(0.09005)$ & $(0.17586)$ & $(0.18599)$ & $(0.03171)$ & $(0.30904)$ & $(0.31104)$ & $(0.39806)$ & $(7.34468)$ \\
\hline & {$[2.65162]$} & {$[0.46582]$} & {$[0.09525]$} & {$[0.19263]$} & {$[-0.09865]$} & {$[0.23144]$} & {$[0.28072]$} & {$[-0.54579]$} \\
\hline R-squared & $\mathbf{0 . 7 9 5 1 6 6}$ & $\mathbf{0 . 7 0 5 0 3 8}$ & $\mathbf{0 . 6 7 5 8 3 8}$ & $\mathbf{0 . 5 6 6 3 8 1}$ & $\mathbf{0 . 4 8 0 7 8 6}$ & $\mathbf{0 . 6 4 0 0 3 0}$ & $\mathbf{0 . 8 5 5 6 2 8}$ & $\mathbf{0 . 4 1 5 1 4 7}$ \\
\hline
\end{tabular}

Source: Author's Computation, 2018

\section{Impulse Response}

An impulse response function (IRF) traces the effect of Cholesky one standard deviation shock in the innovations of one variable, in a current period (horizon), on itself and innovations in other endogenous variables. A shock generated in one variable does not only directly affect that variable, but it is also transmitted to other endogenous variables indirectly through the dynamic lag structure of the Vector Auto Regression (VAR). At any rate, IRF results describe the responsiveness of innovations to Cholesky one standard deviation or exogenous shocks over time.

Table 4. Summary of the Impulse Response of LGDP from Endogenous Variables

\begin{tabular}{|c|c|c|c|c|c|c|c|c|}
\hline Period & DLGDP & DLMCAP & DLASI & DLNLE & DLNOD & DLVOD & DLVTRAN & DSMT \\
\hline 1 & 0.150073 & 0.000000 & 0.000000 & 0.000000 & 0.000000 & 0.000000 & 0.000000 & 0.000000 \\
\hline & $(0.02081)$ & $(0.00000)$ & $(0.00000)$ & $(0.00000)$ & $(0.00000)$ & $(0.00000)$ & $(0.00000)$ & $(0.00000)$ \\
\hline 2 & 0.005321 & 0.063631 & -0.070911 & -0.003406 & -0.086475 & -0.011054 & -0.0797 & -0.03452 \\
\hline & $(0.05185)$ & $(0.04941)$ & $(0.05443)$ & $(0.05464)$ & $(0.05317)$ & $(0.02256)$ & $(0.03815)$ & $(0.03244)$ \\
\hline 3 & 0.030476 & -0.059586 & -0.036975 & 0.070932 & 0.040444 & 0.018717 & -0.00274 & -0.06794 \\
\hline & $(0.06275)$ & $(0.07484)$ & $(0.07035)$ & $(0.07831)$ & $(0.06117)$ & $(0.02444)$ & $(0.06447)$ & $(0.04486)$ \\
\hline 4 & -0.00811 & 0.030549 & 0.010885 & 0.065606 & -0.049171 & -0.010985 & 0.044057 & 0.087458 \\
\hline & $(0.07138)$ & $(0.08921)$ & $(0.07332)$ & $(0.09934)$ & $(0.08542)$ & $(0.02942)$ & $(0.07185)$ & $(0.05149)$ \\
\hline 5 & -0.067247 & 0.073671 & 0.084269 & -0.04227 & 0.059956 & 0.002381 & -0.01965 & -0.01874 \\
\hline & $(0.07436)$ & $(0.08837)$ & $(0.08673)$ & $(0.10006)$ & $(0.09421)$ & $(0.02347)$ & $(0.06785)$ & $(0.05347)$ \\
\hline 6 & 0.019800 & 0.011469 & -0.050004 & -0.006778 & -0.026608 & 0.005591 & 0.009093 & -0.04382 \\
\hline & $(0.07464)$ & $(0.08390)$ & $(0.09570)$ & $(0.10001)$ & $(0.09823)$ & $(0.02819)$ & $(0.07222)$ & $(0.05962)$ \\
\hline 7 & 0.035347 & -0.018478 & 0.008590 & 0.008342 & -0.015783 & -0.019112 & -0.02574 & 0.047112 \\
\hline & $(0.07861)$ & $(0.07967)$ & $(0.09218)$ & $(0.10010)$ & $(0.09645)$ & $(0.02960)$ & $(0.07509)$ & $(0.05885)$ \\
\hline 8 & -0.049816 & 0.058429 & 0.037169 & 0.118792 & 0.068930 & 0.015082 & -0.02546 & -0.0169 \\
\hline & $(0.08009)$ & $(0.08330)$ & $(0.08927)$ & $(0.11579)$ & $(0.09480)$ & $(0.02631)$ & $(0.05393)$ & $(0.05870)$ \\
\hline 9 & 0.027990 & -0.013793 & -0.06258 & -0.029471 & -0.06627 & -0.000276 & 0.010042 & -0.0165 \\
\hline & $(0.09041)$ & $(0.08509)$ & $(0.10764)$ & $(0.11097)$ & $(0.10920)$ & $(0.03021)$ & $(0.06412)$ & $(0.06476)$ \\
\hline 10 & 0.020270 & -0.033624 & -0.005096 & -0.037219 & 0.018132 & -0.017361 & -0.0023 & 0.019126 \\
\hline & $(0.09327)$ & $(0.09407)$ & $(0.09033)$ & $(0.11941)$ & $(0.10333)$ & $(0.03556)$ & $(0.07559)$ & $(0.06778)$ \\
\hline
\end{tabular}

Source: Author's Computation, 2018

Results, in Table4, above, show that, in the first forecast horizon, innovations in all the variables were mostly driven by own shocks (i.e. gross domestic product) and impulses from other variables in the model (i.e. capital market transmission channels or indicators). In the first period (year), there was no response to impulses from other variables (i.e. capital market indicators), as they all had impulse responses of 0.000000 , but there was moderate impulse response to own shock with 0.1500 (i.e. 15\%). In the second period, gross domestic product responded to impulses or shocks from market capitalization at $6.36 \%$ (0.063631), while its impulse response to other variables was negative: all-share index (-0.070911), number of listed equities (-0.003406), number of deals(-0.086475), value of deals $(-0.011054)$, value of transactions $(-0.079700)$ and stock market turnover $(-0.034520)$.

In the third period, gross domestic product responded positively to impulses from number of listed equities, number of deals, and value of deals at 0.070932 , 0.040444 , and 0.018717 respectively, but responded 
negatively to impulses from market capitalization, all-share index, value of transactions and stock market turnover at $0.059586,-0.036975,-0.002740$ and -0.067940 respectively. However, in the fourth period, gross domestic product responded negatively to own shocksand impulses from number of deals and value of deals at $-0.00811,-0.049171$, and -0.010985 respectively, but responded positively to impulses from market capitalization, all-share index, number of listed equities, value of transactions, and stock market turnover at $0.030549,0.010885,0.065696,0.044057$ and 0.087458 respectively.

Furthermore, in the fifth period, the responses of gross domestic product to own shocks and impulses from number of listed equities, value of transactions and stock market turnover were negative at $-0.067247,-0.04227$, 0.01965 and -0.01874 respectively, but to market capitalization, all-share index, number of deals and value of deals, it was positive at $0.073671,0.084269,0.059956$ and 0.02381 respectively. In the sixth year, it was revealed that, shocks from own innovations and impulses from market capitalization, value of deals and value of transactions were positive, while its responses to impulses from other capital market indicators were negative. In the seventh year, gross domestic product responded positively to its own shocks and impulses from all-share index, value of deals and value of transactions, while it responded negativelyto shocks from other capital market indicators.

In the eighth year,own shocks, value of transactions and stock market turnover transmitted negative impulses to gross domestic product, while other capital market indicators transmitted positive impulses to it. In the ninth year, own shocks and impulses from only value of transactions were positive, while impulses from other capital market indicators were negative. Finally, in the tenth year, gross domestic product responded positively to own shocks and impulses from number of deals and value of transactions, while it responded negatively to impulses from other capital market indicators. Ultimately, the results show that, all the capital market transmission channels or indicators employed impacted significantly on the real sector in Nigeria, whose proxy is gross domestic product.
Figure 1: Impulse Response Graph

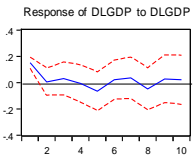

Response of DLMCAP to DLGD

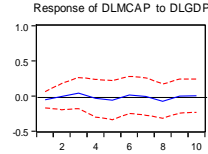

Response of DLASI to DLGDP

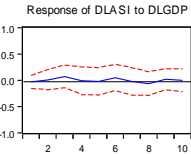

Response of DLNLE to DLGD

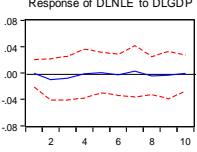

Response of DLNOD to DLGD
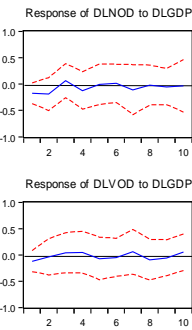

Resonse of DLVTRAN to DLGD

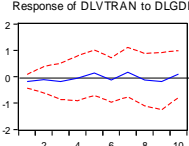

Response of DSMT to DLGDP

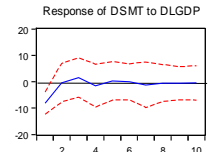

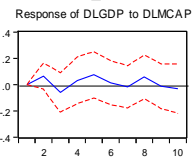

Response of DLMCAP to DLMC,
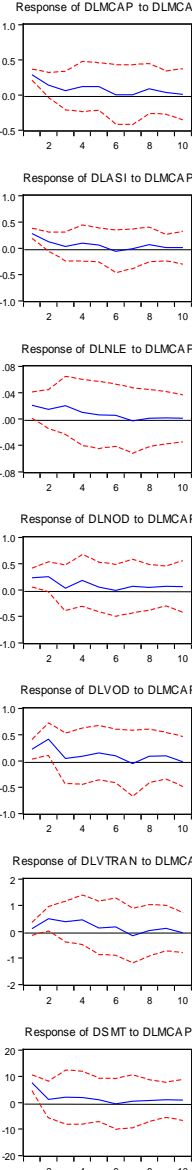
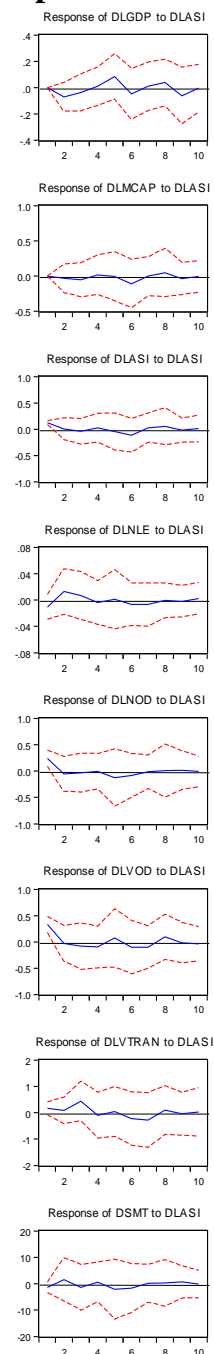
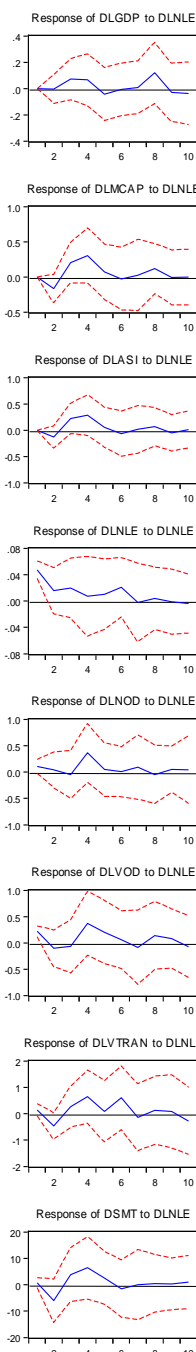
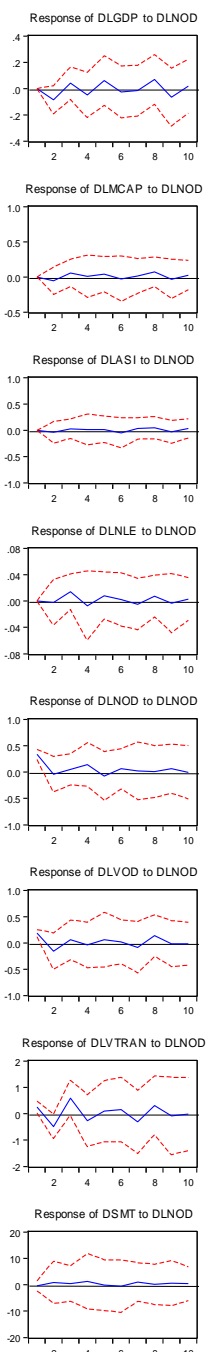
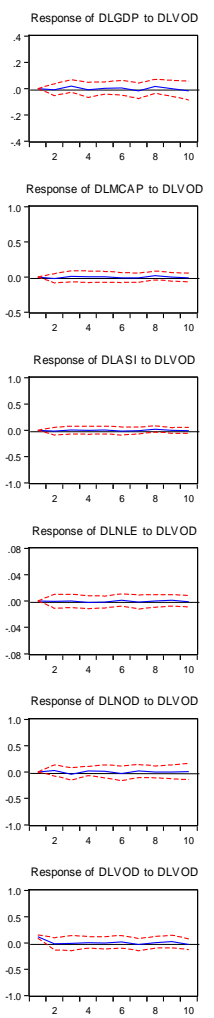

Response of DLVTRAN to DLVOD
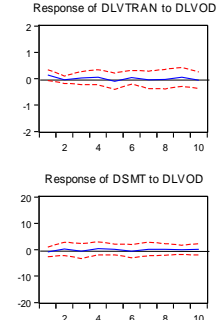
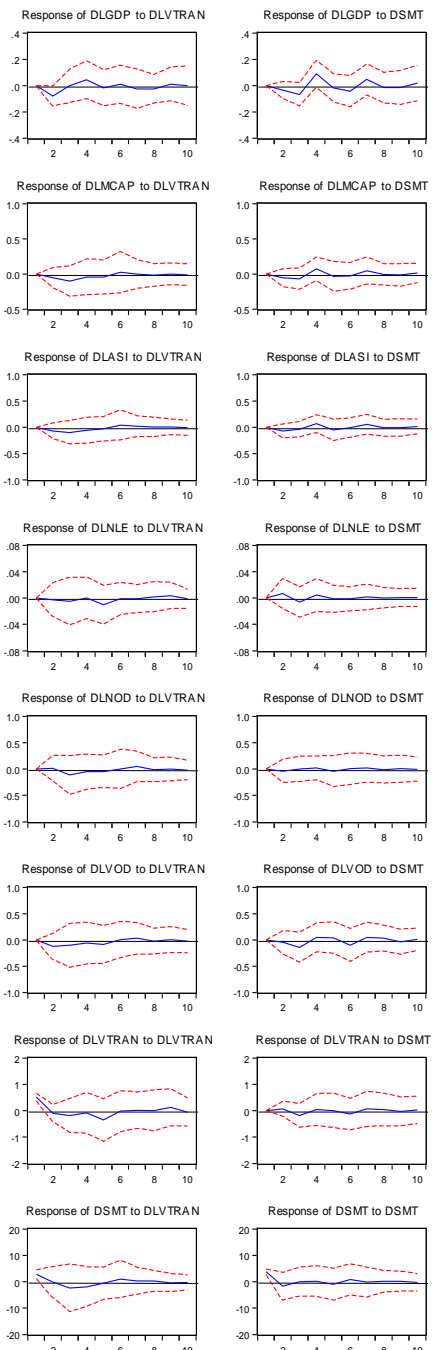
Economic Growth"

\section{Variance Decomposition}

Given the different levels at which each capital market channel and/ orindicator transmitted impulses to the real sector of the economy in Nigeria, it is difficult to isolate the most relevant channel through which capital market impulses are transmitted to the real sector as a basis of influencing economic growth. Therefore, to establish this specific channel of capital market impulses, the variance decomposition error approach was employed. As such, the capital market performance indicator, which accounts for the largest proportion of variations, in gross domestic product, is to be taken as the most significant channel through which capital market impulses are transmitted to the real sector of the economy, hence the results from the variance decomposition estimates generated from unrestricted VAR models for forecast horizon of the first ten years.

From Table 5, below, which displays the results of the variance decomposition error, in the first year, gross domestic product has highest variation of $100 \%$ in itself without any impulse from the endogenous variables employed, that is, capital market performance indicators. In the second year, number of deals accounted for the largest proportion of variations in gross domestic product with a value of 15.98454; value of transactions accounted for the second largest variation with a value of 13.57676; all-share index accounted for the third largest variation with a value of 8.654716; stock market turnover accounted for the fourth largest variation with a value of 2.546965 ; and others had values, which are less than 1 .

In the third year, number of deals, still, accounted for the largest variation in gross domestic product but with a value of 14.18034 , followed by market capitalization with a value of 11.82422 , while value of deals accounted for the least variation in gross domestic product with a value of 0.735202. In the fourth year, stock market turnover accounted for the highest variation in gross domestic product with a value of 16.44656 , followed by number of deals with a value of 14.09371, while value of deals, still, accounted for the least variation in gross domestic product but with a value of 0.724981 .

In the fifth year, the contribution of stock market turnover to variations in gross domestic product dropped from 16.44656 to 13.15069 , while number of deals picked again to account for the highest variation in gross domestic product with a value of 14.40654 , followed by market capitalization with a value of 13.29596. In the sixth year, the variations in gross domestic product were significantly influenced by joint impulses from all-share index, number of deals and stock market turnover with their respective values of 14.54391, 14.28976 and 14.19406; still, value of deals accounted for the least variation in gross domestic product but with a value of 0.568653 .

The seventh year showed that, stock market turnover contributed to the largest variation in gross domestic product with a value of 15.46702 , and value of deals, still, contributed the least to variations in gross domestic product but with a value of 0.857797 .In the eighth year, number of listed equities accounted for the largest variation in gross domestic product with a value of 17.69293, followed by number of deals with a value of 14.53513 , and equivalent effects of stock market turnover, market capitalization, and all-share index with their respective values of $12.72022,12.45087$ and 12.25834 .

In the ninth year, number of listed equities accounted for the largest variation in gross domestic product with a value of 17.04734, number of deals accounted for the second largest variation with a value of 16.39527, and allshare index accounted for the third largest variation with a value of 13.96521; yet, value of deals accounted for the least variation but with a value of 0.794804 . This condition was repeated in the tenth year in the same order: number of listed equities (17.49801), number of deals (16.19283), all-share index (13.63177), and value of deals (0.965880).

This implies that, in the first year, variations in gross domestic product were mostly driven by own shocks, while in the second and third year, variations in gross domestic product were mostly driven by number of deals. In the fourth year, variations in gross domestic product were mostly driven by stock market turnover, while in the fifth year, they were mostly driven by number of deals. It came back to all-share index in the sixth year; however, it was the turn of stock market turnover in the seventh year. Lastly, in the eight year, through the ninth year, to the tenth year, variations in gross domestic product were mostly driven by number of listed equities. Therefore, it can be deduced that number of deals, number of listed equities, stock market turnover and all-share index are the variables causing more variations in gross domestic product, while value of deals does not have much effect on variations in gross domestic product.

Table 5. Summary of Variance Decomposition Error Results of LGDP

\begin{tabular}{|c|c|c|c|c|c|c|c|c|c|}
\hline Period & S.E. & DLGDP & DLMCAP & DLASI & DLNLE & DLNOD & DLVOD & DLVTRAN & DSMT \\
\hline 1 & 0.150073 & 100.0000 & 0.000000 & 0.000000 & 0.000000 & 0.000000 & 0.000000 & 0.000000 & 0.000000 \\
\hline 2 & 0.216293 & 48.20255 & 8.654716 & 10.74848 & 0.024793 & 15.98454 & 0.261199 & 13.57676 & 2.546965 \\
\hline 3 & 0.253515 & 36.53207 & 11.82422 & 9.951102 & 7.846439 & 14.18034 & 0.735202 & 9.894279 & 9.036343 \\
\hline 4 & 0.286042 & 28.77653 & 10.42857 & 7.961448 & 11.42388 & 14.09371 & 0.724981 & 10.14432 & 16.44656 \\
\hline 5 & 0.324029 & 26.73185 & 13.29596 & 12.96755 & 10.60412 & 14.40654 & 0.570359 & 8.272922 & 13.15069 \\
\hline
\end{tabular}



Economic Growth"

\begin{tabular}{|c|c|c|c|c|c|c|c|c|c|}
6 & 0.332877 & 25.68344 & 12.71724 & 14.54391 & 10.08935 & 14.28976 & 0.568653 & 7.913583 & 14.19406 \\
\hline 7 & 0.340643 & 25.60246 & 12.43822 & 13.95191 & 9.694524 & 13.86030 & 0.857797 & 8.127771 & 15.46702 \\
\hline 8 & 0.378602 & 22.45732 & 12.45087 & 12.25834 & 17.69293 & 14.53513 & 0.853102 & 7.032073 & 12.72022 \\
\hline 9 & 0.392253 & 21.43056 & 11.72294 & 13.96521 & 17.04734 & 16.39527 & 0.794804 & 6.616652 & 12.02723 \\
\hline 10 & 0.397261 & 21.15399 & 12.14561 & 13.63177 & 17.49801 & 16.19283 & 0.965880 & 6.454220 & 11.95768 \\
\hline
\end{tabular}

Source: Author's Computation, 2018

\section{VAR Granger Causality Test}

The study also employed Granger causality test in the VAR environment to establish causal relationship between capital market transmission channels and economic growth in Nigeria for the period 1984- 2016. The decision rule of the VAR granger causality test is that, if the F statistic is less than 3.84, the null hypothesis of 'no causal relationship' should be retained, and if the F-statistic is greater than 3.84, the null hypothesis should be rejected, while the alternate hypothesis should be accepted, as there is causal relationship. Also, using the p-value criterion, if the p-value is less than 0.05 , that is, $5 \%$ level of significance, there exists a causal relationship; and as such, the null hypothesis, of 'no causal relationship', should be rejected, while the alternate hypothesis should be accepted. But if the p-value is greater than 0.05 , there exists no causal relationship; hence, the null hypothesis, of 'no causal relationship', should be retained.

From Table 6, below, which shows the results of VAR Granger causality test, it is obtainable that, unidirectional causality exists in the forms: MCAP-GDP; SMT-GDP, NLE-MCAP, and NOD-VTRAN. The implications of these are: First, a unidirectional causality runs from market capitalization (savings-investment channel) to gross domestic productwith an F-statistic of 6.923405 , which is greater than the threshold of 3.84, and a p-value of 0.0314 , which is less than 0.05 ; hence, the null hypothesis, which states that, market capitalization does not granger-cause gross domestic product, was rejected, and the alternate hypothesis was accepted. Second, a unidirectional causality runs from stock market turnover (liquidity transformation channel) to gross domestic product with an F-statistic of 6.112892 , which is greater than the hurdle rate of 3.84 , and a p-value of 0.0471 , which is less than 0.05 ; therefore, the null hypothesis, which states that, stock market turnover does not granger-cause gross domestic product, was rejected, and the alternate hypothesis was accepted.

Third, a unidirectional causality runs from number of listed equities (in the savings-investment channel) to market capitalization (in the same savings-investment channel) with an F-statistic of 7.046104, which is greater than the cut-off point of 3-84, and a p-value of 0.0295, which is less than 0.05 . As such, the null hypothesis, which states that, number of listed equities does not granger-cause market capitalization, was rejected, and the alternate hypothesis was accepted. Lastly, a unidirectional causality runs from number of deals (liquidity transformation channel) to value of transactions (wealth creation channel) with an F-statistic of 7.950328, which is greater than the hurdle rate of 3.84 , and a p-value of 0.0188 , which is less than 0.05.Hence, the null hypothesis, which states that, number of deals does not granger-cause value of transactions, was rejected, and the alternate hypothesis was accepted. On the whole, it is evident that, two of the capital market transmission channels granger-caused gross domestic product (i.e. real sector performance) in Nigeria. These two channels are the savings-investment channel and the liquidity transformation channel. Therefore,there is evidence of unidirectional causality between capital market transmission channels and real sector performance in Nigeria.

Table 6. Summary of Granger Causality Test Results in VAR Environment

\begin{tabular}{|c|c|c|c|c|c|}
\hline \multicolumn{6}{|c|}{ Dependent variable: DLGDP } \\
\hline Excluded & Chi-sq & Df & Prob. & Decision & Causality \\
\hline DLMCAP & 6.923405 & 2 & 0.0314 & Reject Ho & Yes \\
\hline DSMT & 6.112892 & 2 & 0.0471 & Reject Ho & Yes \\
\hline All & 33.95289 & 14 & 0.0021 & & \\
\hline \multicolumn{6}{|c|}{ Dependent variable: DLMCAP } \\
\hline Excluded & Chi-sq & Df & Prob. & Decision & Causality \\
\hline DLNLE & 7.046104 & 2 & 0.0295 & Reject Ho & Yes \\
\hline All & 18.45402 & 14 & 0.1869 & & \\
\hline \multicolumn{6}{|c|}{ Dependent variable: DLASI } \\
\hline Excluded & Chi-sq & Df & Prob. & Decision & Causality \\
\hline All & 15.547 & 14 & 0.3418 & Accept Ho & \\
\hline
\end{tabular}



Economic Growth"

\begin{tabular}{|l|c|c|c|c|c|} 
Dependent variable: DLNLE & & & & \\
\hline Excluded & Chi-sq & Df & Prob. & Decision & Causality \\
\hline All & 5.499649 & 14 & 0.9776 & & \\
\hline Dependent variable: DLNOD & & & & & \\
\hline Excluded & Chi-sq & Df & Prob. & Decision & Causality \\
\hline All & 8.29238 & 14 & 0.8735 & & \\
\hline Dependent variable: DLVOD & & & & & \\
\hline Excluded & Chi-sq & Df & Prob. & Decision & Causality \\
\hline All & 14.7075 & 14 & 0.3984 & & \\
\hline Dependent variable: DLVTRAN & & & & & \\
\hline Excluded & Chi-sq & Df & Prob. & Decision & Causality \\
\hline DLNOD & 7.950328 & 2 & 0.0188 & Reject Ho & yes \\
\hline All & 47.7369 & 14 & 0 & & \\
\hline Dependent variable: DSMT & & & & & Causality \\
\hline Excluded & Chi-sq & Df & Prob. & Decision & \\
\hline All & 6.03109 & 14 & 0.9657 & & \\
\hline
\end{tabular}

Source: Author's Computation, 2018

\section{Discussion of Findings}

Having examined the effects of capital market transmission channels on economic growth in Nigeria through the real sector, the following findings emanated from the study: Primarily, capital market variables exerted heterogeneous effects on gross domestic product in Nigeria. For, while number of listed equities, value of deals, value of transactions and market capitalization exerted positive effects on gross domestic product, all-share index, number of deals and stock market turnover exerted negative influences on it. The implication of this is that, the savingsinvestment channel (proxied by number of listed equities and marketcapitalization) and the wealth creation channel (represented by value of deals and value of transactions) positively contributed to economic growth in Nigeria, while the efficiency channel (proxied by all-share index) and the liquidity transformation channel (represented by number of deals and stock market turnover) negatively contributed to economic growth, in Nigeria, within the study period.

The reasons adducible to the foregoing findings are: First, the savings-investment channel has been effective in mobilizing medium to long-term capital funds required for productive investments that would engender economic growth, in Nigeria, from the standpoint of output approach to national income. Second, the wealth creation channel has been effective in moving both the surplus and deficit spending units close to utility maximization from their current endowment position. The former must have effectively been earning returns on their investments in the form of dividend (including capital appreciation) or interest. Also, the latter must have effectively been earning returns on their investments in the form of profits from the commitment of their raised funds into productive investments, thus increasing the national income from the standpoint of income approach.

Third, for the efficiency channel to have contributed negatively to economic growth in Nigeria, it means that, there must have been regulatory laxity and inefficiencies in the Nigerian capital market, to the extent that, the general market efficiency is so low that, it transmitted negative impulses to the real sector of the economy, as such there is the need for its immediate prompt sanitization. Fourth, the liquidity transformation channel must have been ineffective, through the secondary market activities of the Nigerian capital market, in creating liquidity and marketability of listed securities. This may have been compounded by market infractions and insider abuses, thus resulting in investors losing confidence in the Nigerian capital market.

Transposing gross domestic product against each of the capital market variables, it was found that, gross domestic product exerted positive influences on only number of deals and stock market turnover, that is, liquidity transformation channel. However, it exerted negative influences on efficiency, savings-investment and wealth creation channels. The implication of this is that, a rising gross domestic product, which is not occasioned by a rising capital market performance would have negative influence on the capital market performance indicators with the exception of the proxies of liquidity transformation channel. Thus, this finding provides a scientific solution to the puzzle and worry expressed by Ayodeji and Ajala (2018) that, 'despite output growth, which was supposed to be influenced by capital market performance, as provided for by theories, the key capital market indicators have been fluctuating and nose-diving. This poses a worry, as there was apparent growth without increasing capital market performance; and as such, there was the need to investigate 
whether there can be growth without capital market performance'.

Secondarily, it was found that, capital market variables transmitted heterogeneous impulses to the real sector of the Nigerian economy: While gross domestic product responded more negatively to impulses from stock market turnover and number of listed equities as well as allshare index and value of deals, it responded more positively to impulses from market capitalization, number of deals and value of transactions. The implications of these are that:The liquidity transformation channel transmitted heterogeneous impulses (negative impulses from stock market turnover, but positive impulses from number of deals). Savingsinvestment channel transmitted heterogeneous impulses (negative impulses from number of listed equities, but positive impulses from market capitalization). Wealth creation channel transmitted heterogeneous impulses (negative impulses from value of deals, but positive impulses from value of transactions). However, the efficiency channel (all-share index) transmitted only negative impulses.

The reasons adducible to all these are: First, stock market turnover measures the number of times securities are traded over and over again; these are mere activities, which may have resulted from low corporate performances with existing investors selling off their investments at lower prices. However, number of deals is a reflection of the marketability of securities on the stock exchange, so that an increasing marketability of securities should result in an increasing gross domestic product. Second, the number of listed equities may not be enough to engender the needed growth; however, market capitalization, which is a reflection of available medium to long-term public capital, may have been judiciously committed to productive investments that may engender output growth. Third, value of deals is the expression of price multiplied by number of deals: for, securities prices had been falling on the Nigerian Stock Exchange, though number of deals had been increasing. Fourth, the general market efficiency of the Nigerian capital market was low, thus transmitting negative impulses to the real sector of the economy.

Thirdly, it was found that, number of deals, number of listed equities, stock market turnover and all-share index are the capital market variables causing more variations in gross domestic product, while value of deals does not have much effect on the variations in gross domestic product. The implications of these are that: Liquidity transformation channel (number of deals and stock market turnover) influences more variations in gross domestic product, followed by a partial effect of the savings-investment channel (reflected by number of listed equities only). However, the wealth creation channel (through value of deals) insignificantly influences variations in gross domestic product.
The reasons adducible to these findings are: First, a liquid capital market is an active capital market, which is capable of influencing variations in gross domestic product. This is in line with the opinions of Adenuga (2010) and Mishra et al (2010) as previously enunciated. Second, the savings-investment channel mobilizes medium to long-term funds for listed companies to commit into productive investments that are capable of influencing variations in the level of industrial production in the economy, hence gross domestic product. This is in tandem with the assertions of Osaze (2000), Ekundayo (2002) and Briggs (2015) as indicated earlier.

Therefore, the findings of this study are partially in support of the endogenous growth model of the financegrowth theory, which expects that, capital market would transmit only positive impulses to the economy, hence economic growth. This is due to the fact that, this study found that, capital market variables transmitted heterogeneous impulses (both positive and negative) to the real sector of the economy, depending on the element of the transmission channel that caused more variations in economic growth. Also, the findings of this study are not totally in line with those of the previous studies like those of Carporaleet al (2004), Vazakidis and Adamopoulos (2009), Anigbogu and Nduka (2014) and Taiwoet al (2016): for, these individually found that, capital market variables transmitted positive impulses to the economy.

Having examined the direction of causal relationship between capital market transmission channels and economic growth in Nigeria, using VAR Granger causality test, the following findings were obtained: First, a unidirectional causality runs from market capitalization (savings-investment channel) to gross domestic product (economic growth). Second, a unidirectional causality runs from stock market turnover (liquidity transformation channel) to gross domestic product (economic growth). Third, a unidirectional causality runs from number of listed equities (in the savings-investment channel) to market capitalization (also in the savings-investment channel). Lastly, a unidirectional causality runs from number of deals (liquidity transformation channel) to value of transactions (wealth creation channel).

The implication of all these are that, the savingsinvestment and the liquidity transformation channels are the effective capital market transmission channels that induce (i.e. granger-cause) economic growth in Nigeria. Also, an element in the savings-investment channel (i.e. number of listed equities) induces the other element in the same channel (i.e. market capitalization). Lastly, the liquidity transformation channel (through the number of deals) induces an element in the wealth creation channel (i.e. value of transactions).Consequently, the findings of this study on the direction of causality are in support of the endogenous growth model of the finance-growth theory, which expects capital finance (i.e. capital market variables) to induce 
economic growth, and not in the other way round. The findings of this study are also at tune with those of the previous researchers like Carporaleet al (2004) and Olweny and Kimani (2011), who found a unidirectional causal relationship between capital market and economic growth, running from the former to the latter.

\section{Conclusion and Recommendations}

The study examined the channels through which capital market impulses are transmitted to the real sector of the economy in the achievement of economic growth in Nigeria within the temporal scope 1984-2016. Taking the endogenous growth model of the finance-growth theory as the theoretical anchor, the study estimated time-series data on gross domestic product (proxy for real sector and/ or economic growth) against capital market transmission channels- efficiency channel, savings-investment channel, liquidity transformation channel and wealth creation channel, using vector auto regression with its accompaniments.

On |Research Hypothesis 1, the apriori expectation is that, capital market variables would exert and transmit positive impulses to the real sector for the achievement of economic growth. However, the study found that, capital market variables exerted heterogeneous effects on and transmitted heterogeneous impulses to the real sector of the Nigerian economy. Not only that, significant variations in gross domestic product were caused by the liquidity transformation channel and partially by the savingsinvestment channel. As a direct consequence of the overriding effect of empirical findings, it was concluded that, capital market transmission channels convey heterogeneous impulses to the real sector of the economy with liquidity transformation and savings-investment channels causing the most significant variations in economic growth.

On Research Hypothesis 2, the a priori expectation is that, capital market transmission variables would unilaterally granger-cause economic growth. Conformably, the study found a unidirectional causality running from savings-investment channel to economic growth, and running from liquidity transformation channel to economic growth. So, to this extent, it was concluded that, capital market transmission channels unilaterally induce economic growth through the savings-investment and liquidity transformation channels.

Arising from the findings of this study, the following recommendations were made: First, the Nigerian capital market should be sanitized by fishing out bad eggs from its leadership and operators, and by reinforcing the criminalization of insider abuses and market infractions with stricter acts of parliament, so that public confidence can be restored in the market. Second, more regulatory infrastructures should be developed for the operations of the
Nigerian capital market as additions to the already existing technology-driven Broker Oversight and Supervision System (X-BOSS). The additional infrastructures should be able to reflect the activities of listed companies. Third, training and development programmes, which aim at reorientating the leadership and staff of the Securities and Exchange Commission, towards effective policing of the market, should be embarked upon.

\section{References}

1. Adekunle, O. A., Alalade, Y. S. A., \&Okulenu, S. A. (2016). Macroeconomic variables and its impact on Nigerian capital market growth. International Journal of Economics and Business Management, 2 (2), 22-37

2. Adenuga, A. O. (2010). Stock market development indicators and economic growth in Nigeria (19902009): Empirical investigations. Central Bank of Nigeria (CBN) Economic and Financial Review, 48 (1), 33-70

3. Akingbohungbe, S. S. (1996). The role of the financial sector in the development of the Nigerian economy. Paper presented at a workshop organized by Centre for African Law and Development Studies.

4. Akinlo, A. E., \&Akinlo, O. O. (2009). Stock market development and economic growth: Evidence from seven Sub-Sahara African countries. Journal of Economics and Business,61, 162-171.

5. Anigbogu, U. E., \&Nduka, E. K. (2014). Stock market performance and economic growth: Evidence from Nigeria, employing error correction model framework. The Economics and Finance Letters, 1 (9), 90-103

6. Ayodeji, E. A., \&Ajala, R. B. (2018). Capital market performance and economic growth in Nigeria (1984-2016). Journal of Advances in Social Science and Humanities, 4(11), 362-378

7. Beck, T., Levine, R., \&Laoyza, N. (2000). Finance and the sources of growth. Journal of Financial Economics, 58, 261-300

8. Bencivenga, V. R., \& Smith, B. D. (1991). Financial intermediation and endogenous growth, Review of Economic studies, 52(2), 195-209.

9. Benhabib, J. \& Spiegel, M. M. (2000). The role of financial development in growth and investment. Journal of Economic Growth, 5, 341-360

10. Briggs, A. P. (2015). Capital market and economic growth of Nigeria. Research Journal of Finance and Accounting, 6 (9), 82-93

11. Caporale, G. M., Howells, P., \&Soliman, A. M. (2004). Stock market development and economic growth: The causal linkage. Journal of Economic Development, 29, 33-50 
12. Dabo, Z. (2015). Impact of Nigerian capital market capitalisation on the growth of the Nigerian Economy. Journal of Emerging Issues in Economics, Finance and Banking (JEIEFB), 4 (2), 1513-1524.

13. Easterly, W.,\& Levine, R. (2001). The elusive quest for growth: Economist's adventures and economic growth, The Quarterly Journal of Economics, CVII (2), 407-437

14. Edame, G. E., \& Okoro, U. (2013). The impact of capital market and economic growth in Nigeria. Public Policy and Administration Research, 3 (9), 7-15

15. Ekundayo, I. K. (2002). Creating a conducive environment for investment in the Nigerian capital Market.Paper presented at public enlightenment on opportunities in the capital market for industrial development of Kogi State, Lokoja, 29th March to 1st April, 2002

16. Ewah, S. O. E., Esang, A. E., \&Bassey, J. U. (2009). Appraisal of capital market efficiency on economic growth in Nigeria. International Journal of Business and Management, December, 219-225

17. Fry, M. J. (1988). Money, interest, and banking in economic development. John Hopkins University Press, John Hopkins Studies in Development Series Baltimore and London

18. Greenwood, J., \& Jovanovic, B. (1990). The financial development, growth and the distribution of income. The Journal of Political Economy, 98, 1076-1107

19. King, R. G.,\& Levine, R. (1993). Finance and growth; Schumpeter might be right. Quarterly Journal of Economics, 108 (3), 717-738

20. Levine, R. (1991). Stock markets, growth and tax policy. Journal of finance, 64(4),1445-1465

21. Levine, R., \& Zervos, S. (1996). Stock market development and long-run growth. The World Bank EconomicReview, 10(3), 323-339

22. Mishra, P. K., Mishra, U.S., Mishra, B. R., \& Mishra, P. (2010). Capital market efficiency and economic growth: The case of India. European Journal of Economics, Finance and Administrative Sciences, 27 (18), 130-138

23. Muritala, T. A., \&Ogunji, M. (2017). Does the capital market spureconomic growth?Evidence from Nigeria, Journal of Corporate Finance Research, 11 (1), 90-99

24. Nwaolisa, E. F., Kasie, E. G., \&Egbunike, F. C. (2013). The impact of capital market on the growth of theNigerian economy under democratic rule, Arabian Journal of Business and Management Review (OMAN Chapter), 3 (2), 53-62

25. Oke, M. O., \&Adeusi, S.O. (2012). Impact of capital market reforms on economic growth: The
Nigerian experience. Australian Journal of Business and Management Research, 2 (2), 20-30

26. Olweny and Kimani (2011). Stock market performance and economic growth: Empirical evidence from Kenya, using causality test approach. Advances in Management \& Applied Economics, 1 (3), 153-196

27. Osaze, B. E. (2000).The Nigeria capital market in the African and Global financial System, Benin City: Bofic Consults Group Limited.

28. Otiti, A. O. G. (2007). Essay on recent issues in the Nigerian financial system. Lagos: The Chartered Institute of Bankers (CIBN) Press Limited

29. Pagano, M. (1993). Financial markets and growth: An overview. European Economic Review, 37, 613-622

30. Rolle, R. A., \&Uffie, E. J. (2015). Testing the Solow model in Nigeria's economy. JORIND, 13 (1), 286-297

31. Romer, P. M. (1990). Endogenous technological change, NBER Working Paper 3210, National Bureau of Economic Research, Inc

32. Stimpson, P., \&Farquharson, A. (2015). Cambridge International AS and A Level Business Course Book, Third Edition, London: Cambridge University Press, University Printing House.

33. Taiwo. J. N., Alaka, A., \&Afieroho, E. (2016). Capital market and economic growth in Nigeria. Account and Financial Management Journal, 1 (8), 497-525

34. Vazakidis, A., \& Adamopoulos, A. (2009). Stock market development and economic growth. American Journal of Applied Science, 6(11), 1933 1941

35. World Bank (2000). Entering the $21^{\text {st }}$ century. World Development Report 1999/ 2000. New York: Oxford University Press

36. Yadirichukwu, E., \&Chigbu, E. E. (2014). The impact of capital market on economic growth: The Nigerian perspective. International Journal of Development and Sustainability, 3 (4), 839-847 